\title{
The Utilization of Organic Waste Chicken Cage Fertilizer on the Growth of Cocoa (Theobroma Cacao L.)
}

\author{
Lukman \\ Madako Tolitoli University, Indonesia \\ Email: iffahmasayu02@gmail.com
}

\begin{abstract}
The agricultural sector is the largest contributor of organic waste that can be recycled as useful things, among others, used as organic fertilizer. This study aims to determine the effect of agricultural waste organic compost on the growth of Cocoa (Theobroma Cacao L.) plants. The analysis results of the materials to be applied are N-total: $0.27 \%$ P2O5: $3.20 \%$, K2O: $1.63 \%$, and C-Organic: $17.40 \%$, then the research data were analyzed using a Randomized Block Design (RAK) which consists of 6 levels of treatment, namely: $\mathrm{C} 0=$ no fertilizer, $\mathrm{C} 1=$ soil $+20 \mathrm{~g}$ compost polybag $-1, \mathrm{C} 2=$ soil + compost $40 \mathrm{~g}$. polybag-1, C3 = soil + compost $60 \mathrm{~g}$. polybag-1, C4 = soil + compost $80 \mathrm{~g}$. polybag- $1, \mathrm{C} 5$ = Soil + compost $100 \mathrm{~g}$. polybag- 1 . Each experiment was repeated three times, so there were 90 experimental units. Observation parameters were plant height, number of leaves, and stem diameter. The results showed that, giving $100 \mathrm{~g}$ of organic waste compost polybag-1 gave better results on the growth of cacao seedlings, with a plant height of $29.61 \mathrm{~cm}$, number of leaves 11.73 strands, and stem diameter of $3.38 \mathrm{~mm}$. From this research, it can be concluded that it will produce better results if organic waste is managed properly.
\end{abstract}

Keywords: Cocoa, Compost, Waste, Organic.

\section{A. INTRODUCTION}

Cocoa (Theobroma Cacao L.) is a plantation crop that generally grows in the tropics. The part of the cocoa pod that is used is in the form of seeds, which are then processed in such a way as to produce cocoa powder, commonly used as refreshments and snacks. In the cultivation process, before being transferred to the planting area, a nursery is carried out and maintained to get good seeds, one of the obstacles in the growth of cocoa seedlings is the lack of available nutrients in the soil (Same, 2011). With the provision of appropriate fertilizer with the correct dose so that it is hoped that the growth of cocoa plants can be better. One form of fertilizer that is recommended to be used is organic fertilizer.

Organic fertilizers have complete nutrients, both macro and micronutrients, and other elements such as hormones that can benefit plants. The continuous use of inorganic fertilizers will cause physical damage to the soil; the scarcity and high price of inorganic fertilizers is also a problem faced in cocoa nurseries (Dewi Riniarti et al., 2013). Good crop production is strongly influenced by the quality of the seeds used; in addition, an excellent growing medium for seedlings is a medium that can provide sufficient nutrients. Organic nutrients can come from agricultural and livestock waste, but not many farmers have utilized them; this is due to several 
factors, including how to process them into fertilizers for use and their effects on plants. Based on this background, research was conducted on the utilization of organic waste on the growth of cocoa plant seeds. The novelty value of this research is an organic fertilizer made by itself with total nutrient content of $\mathrm{N} 0.27 \%$, P2O5 $3.20 \%$, K2O 1.63\%, C-Organic 17.40\% (Lukman, 2019b).

\section{B. METHOD}

The materials used are: Cocoa seeds, Cocoa beans planted in the nursery are first selected to get quality cocoa seeds, then the cocoa beans are sown in burlap sacks for five days. After the seeds grow and then planted in polybags without treatment. Polybags used size $10 \times 15 \mathrm{~cm}$, soil that has been sifted or mashed, waste that becomes compost. At the same time, the tools used are hoes, shovels, machetes, rulers, calipers, scales, boards, nets, water hoses, paper labels, writing instruments and cameras. Each polybag is filled with soil that has been mixed with organic fertilizer with a weight of $1 \mathrm{~kg}$.

This study used a Randomized Block Design (RAK) with six treatments, where for each treatment, there were five plant populations which were also sampled so that there were 30 plants in each treatment. Each treatment was repeated three times so that there were 90 experimental plants with the following treatments: $\mathrm{f} 0=$ Soil $1000 \mathrm{~g}$ $\mathrm{f} 1=$ Soil $980 \mathrm{~g}+$ Chicken Manure Compost $20 \mathrm{~g}$ $\mathrm{f} 2=$ Soil $960 \mathrm{~g}+$ Chicken Manure Compost $40 \mathrm{~g}$ f3= Soil $940 \mathrm{~g}+$ Chicken Manure Compost $60 \mathrm{~g}$ $\mathrm{f} 4=$ Soil $920 \mathrm{~g}+$ Chicken Manure Compost $80 \mathrm{~g}$ f5= Soil $9009+$ Chicken Manure Compost $100 \mathrm{~g}$

The data obtained were analyzed on variance (Anova). If there is a significant or very significant effect on the treatment, further tests are carried out using the $5 \%$ and $1 \%$ BNJ tests.

\section{RESULT AND DISCUSSION}

\section{Cocoa Seed Height $(\mathrm{cm})$}

The results of observations of the average height of cocoa plants at the age of 2, 4, 6, 8 and 10 Weeks after Planting (WAP) are presented in Figure 1. The variance results indicate that the treatment of various doses of organic chicken coop compost did not significantly affect the growth of plant seeds-cocoa at the age of 2, 4, 6, 8 and $10 \mathrm{WAP}$. The average plant height is presented in Figure 1. 


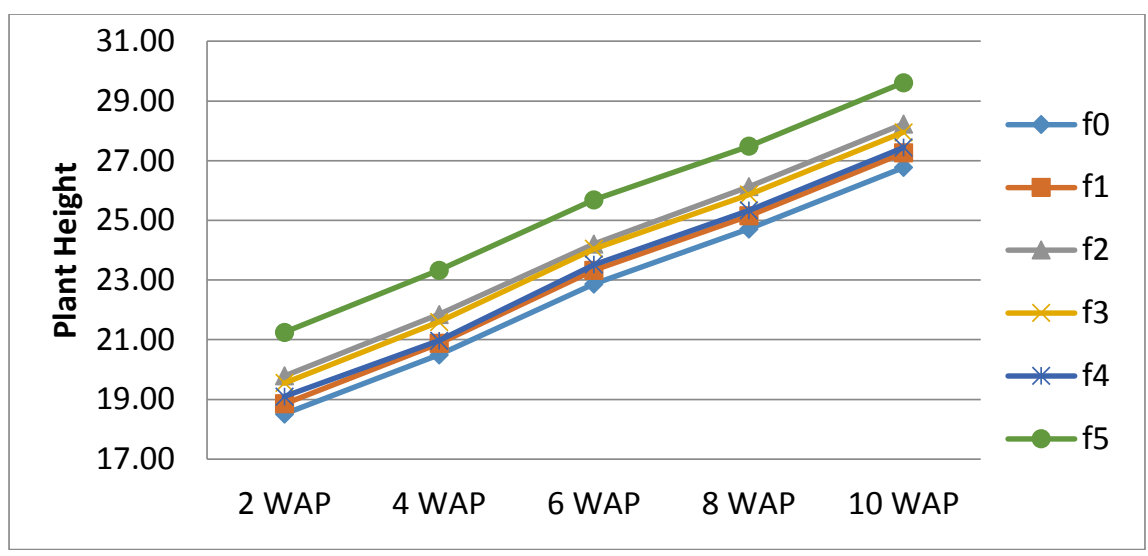

\section{Figure 1 Graph of Average Cocoa Seed Height (cm) Ages 2, 4, 6, 8 and 10 WAP}

Figure 1 shows that the application of chicken manure compost at various compositions did not significantly change the height of the Cocoa WAP plant. In general, giving chicken manure compost showed an effect on the size of cocoa seedlings compared to without chicken manure compost. Cocoa seeds that were given chicken manure compost were better than those not composted. In the f5 treatment, the growth results of seedling height were better than those that were not given chicken manure compost. This is presumably due to the addition of composted chicken manure that has been decomposed so that the nutrients contained in the compost can play a role in increasing the nutrients in the soil; besides that, chicken manure compost is also able to maintain groundwater, so that plants that are given compost show better growth. (Pangaribuan et al., 2017) Nutrients N, P and K available in optimal and balanced quantities will provide a balance of macronutrients for plants.

According to (Augusto. et al., 2017), N's availability in the soil is minimal because $\mathrm{N}$ is more influenced by climate and not the parent material. Thus it is necessary to add $\mathrm{N}$ from decomposed organic matter. (Sajimin, 2011) stated that chicken manure has a higher $\mathrm{N}$ content. It stimulates the growth of plant vegetation faster; giving chicken manure compost will have a good effect on plant roots, develop well, and absorb more nutrients, especially trace elements. $\mathrm{N}$ nutrients will increase the formation of chlorophyll so that photosynthetic activity can grow and increase plant height. (Siswanti \& Umah, 2021) Application of organic fertilizer can increase plant height and the number of leaves with higher chlorophyll content in leaves. Following this (Agustua Sinabariba et al., 2013) also stated that the addition of nitrogen elements into the soil could stimulate meristematic tissue, which is increasingly actively dividing to produce the growth of cocoa seedlings, especially plant height, because the central role of the element $\mathrm{N}$ for plants is to promote plant growth, mainly stems, branches and leaves. This is in line with the opinion (Chemura, 2014); (Dewantara et al., 2017) that the use of organic fertilizers affects primary growth and plant height, and effective uptake of nitrogen $(\mathrm{N})$ nutrients can have a positive impact on plant height. 


\section{Number of Cocoa Seed Leaves (strands)}

The results of observations of the average number of leaves of cocoa plants at the age of 2, 4, 6, 8 and 10 Weeks After Planting (WAP) with the results of fingerprint analysis showed that the treatment of various doses of organic waste fertilizer had no significant effect on the number of leaves of cocoa plants at age 2, 4, 6, 8, and 10 WAP. The average number of plant leaves is presented in Figure 2:

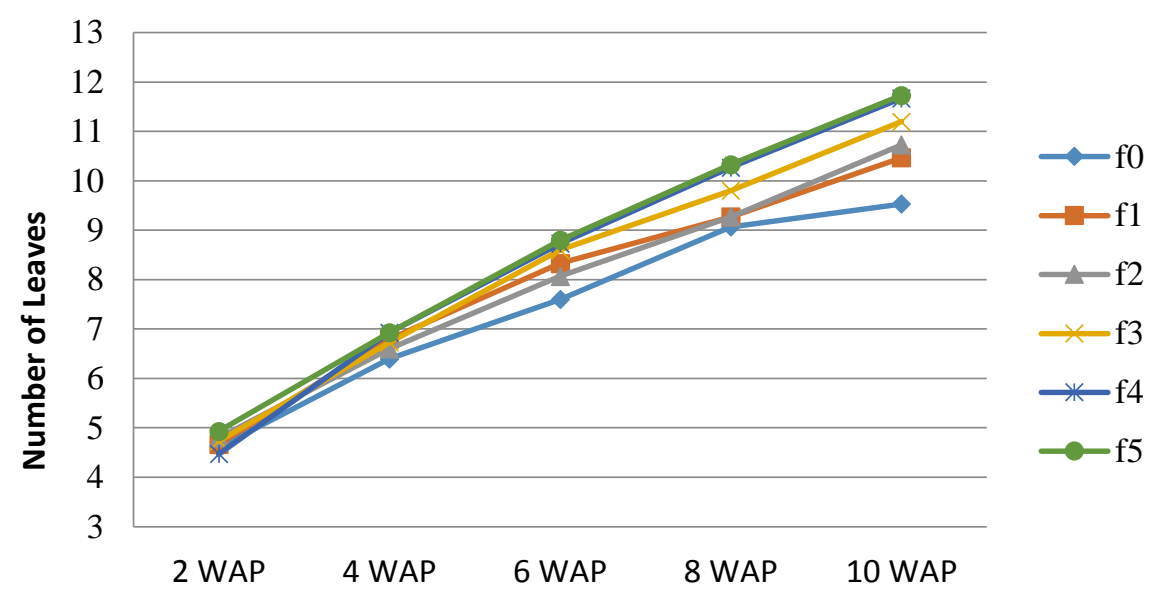

Figure 2 Graph of Average Number of Cocoa Seedling Leaves (strands) at Ages 2, 4, 6, 8 and 10 WAP

Figure 2 shows that the application of chicken manure compost at various doses did not significantly differ from the number of leaves of cocoa plants. Based on these data, it was found that the $\mathrm{f} 5$ treatment showed the highest number of leaves at the ages of $2,4,6,8$ and $10 \mathrm{WAP}$, which were 4.67, 6.73, 8.33, 10.27 and 11.73, respectively, better than F0 treatment. This is presumably due to the increasing doses of chicken manure compost as organic material capable of improving the soil's physical, biological, and chemical properties so that it can increase.

Damanik et al. (2011) stated that chicken manure contains three times more nitrogen than other manure fertilizers. This content can increase the growth and development of plant leaves more than other manure fertilizers. (Lakitan 2012) also stated that the most influential nutrient on leaf growth and development plants in cell division will utilize $\mathrm{N}$. The $\mathrm{N}$ content in plants. Cell division is the outermost three layers of cells on the top surface of the stem. Haslita (2018) states that if the nitrogen supply is sufficient, plant leaves will grow large and expand the surface available for photosynthesis. Increased nutrients such as nitrogen, phosphorus, PotassiumPotassium, where nitrogen elements affect the formation of new cells, phosphorus plays a role in activating enzymes in the photosynthesis process, and PotassiumPotassium affects the development of meristem tissue which can affect leaf length and width.

\section{Cacao Seed Stem Diameter ( $\mathrm{mm})$}

The average yield of cacao stem diameter at 2, 4, 6, 8 and 10 Weeks After Planting (WAP) had no significant effect on the stem diameter of cacao seedlings at 2 , 4, 6, 8, and 10 WAP. The average stem diameter is presented in Figure 3: 


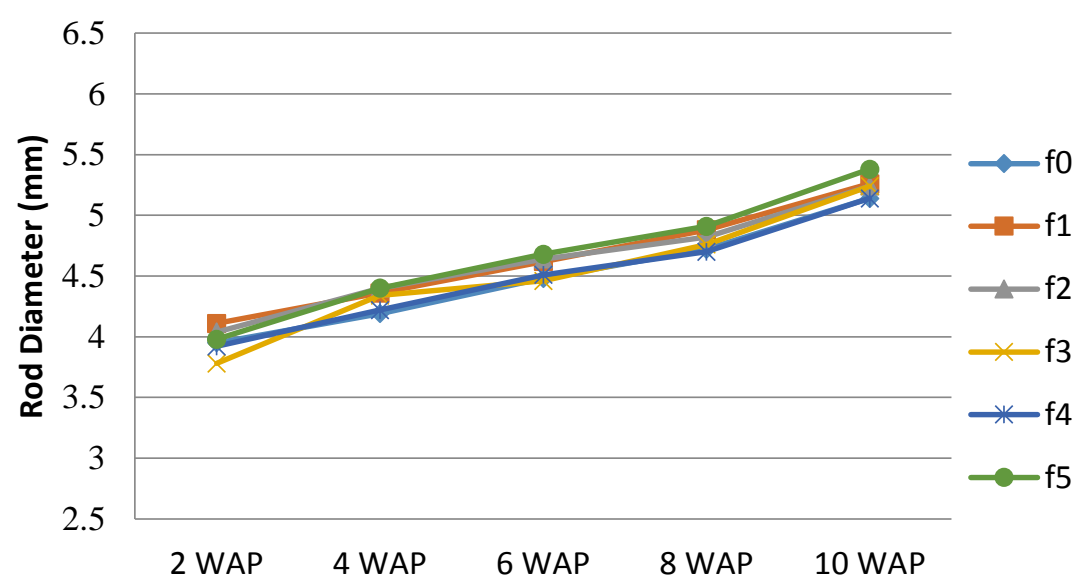

Figure 3 Graph of Average Stem Diameter of Cocoa Seeds (mm) Age 2, 4, 6, 8, and 10 WAP

Figure 3 shows that the application of chicken manure compost at various doses did not significantly affect the stem diameter of cocoa plants. Based on these data, it was found that the F5 treatment showed the highest stem diameters at the ages of 2, 4, 6, 8 and $10 \mathrm{WAP}$, which were 1.98, 2.40, 2.68, 2.91 and 3.38, respectively. Occurred in the $\mathrm{f} 5$ treatment because the planting media that was given chicken manure compost was able to provide growth in stem diameter, the development of stem diameter was influenced by the availability of nutrients $\mathrm{N}, \mathrm{P}$ and $\mathrm{K}$. P element played a role in stimulating plant cell division and enlarging cell tissue. Meanwhile, K nutrient plays a role in strengthening cocoa seedling stems.

Indrawan et al. (2015) suggested that sufficient $\mathrm{N}$ during growth will provide good plant growth, one of which is plant stem growth. Munawar (2011) also stated that plants that lack $\mathrm{P}$ and $\mathrm{K}$ elements cause stem diameter to be small. Greater $\mathrm{N}$ uptake by plants, which increases the concentration of $\mathrm{N}$ in leaves, supports the photosynthesis process and produces taller plants with larger stem diameters Kulmann et al., (2020). This follows the research of Butar Butar et al. (2013), which states that NPK, Mg fertilizers are nutrients for plants that are generally needed for the formation or growth of vegetative parts of plants such as leaves, stems, roots.

\section{Cocoa Seedling Leaf Width $(\mathrm{cm})$}

The analysis of variance showed that the treatment of various doses of organic fertilizer had no significant effect on the leaf width of cocoa plants at 2, 4, 8, and 10 WAP. But it had a significant impact at the age of 6 WAP. The average leaf width $(\mathrm{cm})$ of cacao seedlings in the treatment of organic fertilizer doses at the ages of 2, 4, 6, 8 and $10 \mathrm{WAP}$ is presented in Figure 4: 


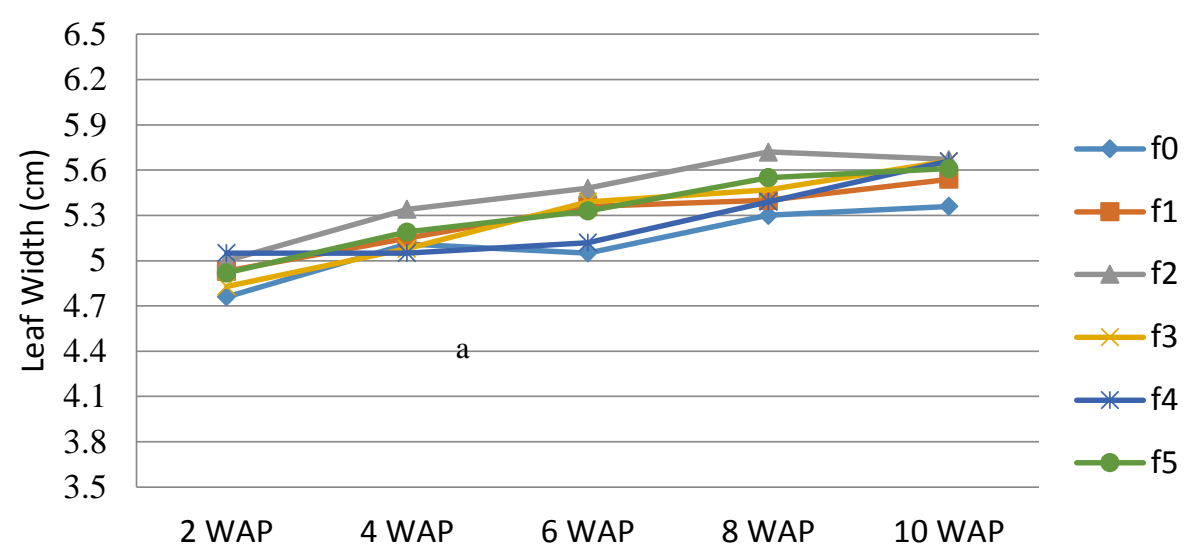

Figure 4 Average Leaf Width of Cocoa Seeds (cm) Age 2, 4, 6, 8, and 10 WAP

Figure 4 shows that the $\mathrm{f} 2$ treatment showed the widest leaf width of cocoa plants at the age of $6 \mathrm{WAP}$, which was $5.48 \mathrm{~cm}$ on average, significantly different from treatment f0 but not substantially different from other treatments. Based on these data, it is known that the widest leaf width is found in the f2 treatment, which is an average of 5.48, while the smallest is obtained in the f0 treatment, which is an average of $5.05 \mathrm{~cm}$. This is because the nutrients needed by cocoa seeds have been fulfilled in this composition. Based on visual observations that the leaves of cacao seedlings look greener than those without treatment, the green color indicates that the chlorophyll content contained in them is more significant, the greater the chlorophyll content, the higher the photosynthate produced, so that cocoa seedlings can use the food reserves in forming leaf area.

From a physiological point of view, leaves are plant organs that have limited growth. The photosynthate produced supports the work of plant tissue cells in differentiation to accelerate the growth and development of planet-forming parts such as leaves, stems and roots. The provision of chicken manure compost can contribute nutrients to plants, especially $\mathrm{N}$, thereby causing photosynthesis to increase. The resulting photosynthate also increases and then be translocated to vegetative growth organs used to improve the leaf area of cocoa seedlings. According to Hakim et al. (2009), that element $\mathrm{N}$ is the main constituent of young plant biomass and plays a role in stimulating vegetative growth, such as stimulating leaf growth.

\section{Cocoa Seed Root Length $(\mathrm{cm})$}

The analysis of variance showed that the treatment with organic fertilizer had no significant effect on root length at the end of the study. The average root length at the end of the survey at various doses of organic fertilizer is presented in Figure 5: 


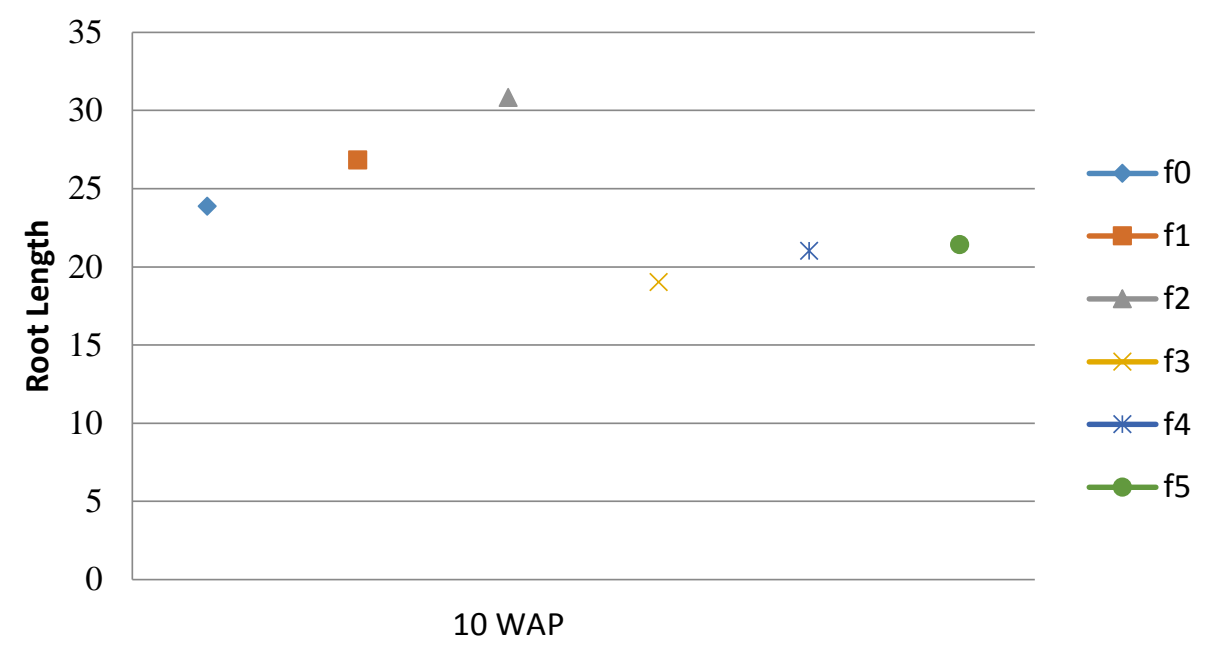

Figure 5. Average Root Length of Cacao Seeds (cm) At Age 10 WAP

The graph in Figure 5 shows that the application of chicken manure compost at various doses did not significantly differ from the most extended root length of cocoa plants. The data showed that the $\mathrm{f} 2$ treatment showed the most extended root length at the end of the study, which was 30.83 . The size of roots obtained by f2 was due to the application of chicken manure compost into the soil in addition to adding nutrients as well as to improve soil physical properties such as better soil structure, as well as to increase soil microorganism activity so that it is beneficial for increasing soil fertility, which in turn can stimulate root growth in the soil. Lakitan (2012) states that the development of the root system will deviate from its ideal condition if the soil conditions as a place to grow are not in optimal conditions. Still, if the opposite occurs, it can be ascertained that genetic factors thoroughly influence the plant's root system. Roots have a hood structure, part of the root trunk, branches, and root hairs that function as a place to absorb nutrients by spreading so make the absorption area-wide, allowing for water and nutrients to reach. These nutrients can be transported due to differences in the fluid concentration between the cells that are passed; the fluid in the hair is more concentrated than groundwater so that water, soil, and nutrients can enter other cells. The nutrients that the root hairs have absorbed will dissolve and flow to the surrounding cells in a horizontal direction until they finally reach the wood pulp so that the provision of chicken manure compost makes the planting media more brittle so that it can stimulate and facilitate the development of cocoa plant roots to grow longer. In addition, loose soil can bind water and absorb more nutrients. Water is needed by plants, especially in transforming photosynthetic materials to the plants that need it.

Chicken manure compost plays a role in increasing aeration porosity and soil binding capacity to water, facilitating root formation and storing better groundwater; Chicken manure compost as organic material functions in improving soil structure so that the ground becomes loose, easy for air circulation to facilitate roots to develop, including increasing the length of the sources. Besides that, chicken manure compost as an organic material can also improve the chemical properties of the soil, namely by helping the weathering process of mineral materials and can 
provide food for microbial life. In addition to the physical influence of the earth, the result of $\mathrm{P}$ elements contained in the soil also affects supporting the growth of root length; $p$, which is available in sufficient quantities, can stimulate the growth and development of the root system for the better. Plant roots decrease due to inhibition of the rate of photosynthesis.

According to Lukman and Kusrianty (2021), composted chicken manure contains complete nutrients, both macro and micro, and contains hormones, although not in large amounts. XUE Xin-xin et al. (2020) stated that the absorption of $\mathrm{K}$ nutrients that interacted with $\mathrm{Mg}$ significantly affected root length, root surface area, root volume, and the total number of root tips - further stated by Guo et al. (2019) that the K nutrients contained in organic fertilizers are classified as good. At the highest dose, it increases; low PotassiumPotassium affects plant root growth, plant uptake and accumulation of PotassiumPotassium. This can be seen from the study results where the treatment of soil composition with $40 \mathrm{~g}$ chicken manure compost showed a better effect on root length.

\section{CONCLUSION}

Based on the results of the study, it can be concluded that the use of chicken manure compost at a dose of $100 \mathrm{~g}$ gave a better effect on the growth of cacao seedlings, namely, plant height at 10 WAP $29.61 \mathrm{~cm} /$ cocoa seed, several leaves aged 10 WAP 11.73 Cocoa strands/roots, as well as the observation parameter of stem diameter, giving $100 \mathrm{~g}$ of chicken manure compost, also showed promising results, namely an average of $3.38 \mathrm{~mm} /$ cocoa seed at the age of $10 \mathrm{WAP}$.

\section{ACKNOWLEDGEMENT}

Thank you to all those who have helped so that this research and writing is completed, and I hope it can be helpful, especially for farmers, students, and researchers.

\section{REFERENCES}

1. Augusto, L., Achat, D. L., Jonard, M., Vidal, D., \& Ringeval, B. (2017). Soil parent material-A major driver of plant nutrient limitations in terrestrial ecosystems. Global change biology, 23(9), 3808-3824.

2. Butar, M. B., Siagian, B., \& Irsal, I. (2014). Pertumbuhan Bibit Kakao (Theobroma Cacao. 1) Pada Media Subsoil Ultisol Dengan Pemberian Pupuk NPKMG dan Pupuk Kandang Ayam. Jurnal Agroekoteknologi Universitas Sumatera Utara, 2(1), 97047.

3. Chemura, A. (2014). The growth response of coffee (Coffea arabica L) plants to organic manure, inorganic fertilizers and integrated soil fertility management under different irrigation water supply levels. International Journal of Recycling of Organic Waste in Agriculture, 3(2), 59.

4. Damanik, M. M. B., Bacthiar, E. H., Fauzi, S., \& Hamidah, H. (2011). Kesuburan Tanah dan Pemupukan. Medan: USU Press. 
5. de Souza Kulmann, M. S., Stefanello, L. O., Arruda, W. S., Sans, G. A., Parcianello, C. F., Hindersmann, J., ... \& Brunetto, G. (2020). Nitrogen supply methods affect the root growth dynamics in Eucalyptus grandis. Forest Ecology and Management, 473, 118320.

6. Dewantara, F. R., \& Ginting, J. (2017). Respons Pertumbuhan Bibit Kopi Robusta (Coffea robusta L.) Terhadap Berbagai Media Tanam Dan Pupuk Organik Cair: Growth response of robusta coffe seed (Coffea robusta L.) on various growth medium and liquid organic fertilizer. Jurnal Online Agroekoteknologi, 5(3), 676-684.

7. Riniarti, D., Kusumastuti, A., \& Tahir, M. (2013). Pengaruh jenis limbah agro industri terhadap keragaan bibit sawit main nursery pada ultisol. Jurnal Penelitian Pertanian Terapan, 13(2), 123-130.

8. Guo, Z., Li, Z. S., Dai, X., \& Wang, Y. F. (2019). Effects of auxin on tobacco root growth and potassium uptake under low potassium stress. Journal of Plant Nutrition and Fertilizers, 25(7), 1173-1184.

9. Hakim, N., Nyakpa, M. Y., Lubis, A. M., Nugroho, S. G., Saul, M. R., Diha, M. A., ... \& Bailey, H. H. (1986). Dasar-Dasar Ilmu Tanah. Lampung: Universitas Lampung. Lampung.

10. Haslita, H. (2018). Pemanfaatan Eceng Gondok (Eichhornia crassipes) sebagai Kompos terhadap Pertumbuhan Tanaman Cabai Besar (Capsicum annum L.) (Doctoral dissertation, Universitas Islam Negeri Alauddin Makassar).

11. Indrawan, I., Kusumastuti, A., \& Utoyo, B. (2015). Pengaruh pemberian kompos kiambang dan pupuk majemuk pada pertumbuhan bibit kakao (Theobroma cacao L.). Jurnal Agro Industri Perkebunan, 3(1), 47-58.

12. Lakitan, B. (2012). Dasar-Dasar Fisiologi Tumbuhan. Jakarta: Raja Grafindo Persada. 13. Lukman, L. (2019a). Analisis Hara Pupuk Kandang. Laboratorium Tanah, Tanaman, Pupuk dan Air. Balai Penelitian dan Pengembangan Pertanian. (pp. 1-2).

14. Lukman, L., \&Kusrianty, N. (2021). Kombinasi Penggunaan Kompos Eceng Gondok (Eichhornia crassipes) dengan Pupuk Kandang Ayam Terhadap Laju Pertumbuhan Bibit Tanaman Kopi Robusta (Coffea canephora). Jurnal Sains Dan Teknologi, 10(2), 200-210.

15. Munawar. (2011). Kesuburan Tanah danNutrisiTanaman. Bogor: IPB Press.

16. Pangaribuan, D. H., Hendarto, K., \& Prihartini, K. (2017). Pengaruh Pemberian Kombinasi Pupuk Anorganik Tunggal dan Pupuk Hayati Terhadap Pertumbuhan dan Produksi Tanaman Jagung Manis (Zea Mays Saccharata Sturt) Serta Populasi Mikroba Tanah. Jurnal Floratek, 12(1), 1-9.

17. Sinabariba, A., Siagian, B., \& Silitonga, S. (2013). Respons Pertumbuhan Bibit Kakao (Theobroma Cacao. L) Terhadap Pemberian Kompos Blotong Dan Pupuk Npkmg Pada Media Subsoil Ultisol. Jurnal Agroekoteknologi Universitas Sumatera Utara, 1(3), 95302.

18. Sajimin. (2011). Medicago sativa L (Alfalfa) Sebagai Tanaman Pakan Ternak Harapan di Indonesia. Wartazoa, 21(2), 91-98.

19. Same, M. (2011). Pengaruh Jenis Limbah Agro Industri Terhadap Keragaan Bibit Sawit Main Nursery pada Ultisol. Jurnal Penelitian Pertanian Terapan, 11(2), 69-76. 
20. Siswanti, D. U., \& Umah, N. (2021). Effect of Biofertilizer and Salinity on Growth and Chlorophyll Content of Amaranthus tricolor L. IOP Conference Series: Earth and Environmental Science, 662(1), 012019.

21. Xue, X. X., Wei, Y. X., Wang, W. B., Luo, X. H., Zhao, C. M., Wang, D. P., Zhang, Y. F., \& Wu, X. P. (2020). Interaction of Potassium and Magnesium on the Growth and Nutrient Absorption of Hevea brasiliensis seedlings. Journal of Plant Nutrition and Fertilizers, 26(10), 1870-1878. 